\title{
Trends in tropospheric ozone concentrations and forest impact metrics in Europe over the time period 2000-2014
}

\author{
Chiara Proietti ${ }^{1} \cdot$ Maria Francesca Fornasier ${ }^{1}$.

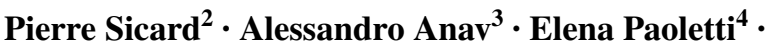 \\ Alessandra De Marco ${ }^{3}$
}

Received: 15 June 2020 / Accepted: 29 July 2020 / Published online: 17 October 2020

(C) The Author(s) 2020

\begin{abstract}
In Europe, tropospheric ozone pollution appears as a major air quality issue, and ozone concentrations remain potentially harmful to vegetation. In this study we compared the trends of two ozone metrics widely used for forests protection in Europe, the AOT40 (Accumulated Ozone over Threshold of $40 \mathrm{ppb}$ ) which only depends on surface air ozone concentrations, and the Phytotoxic Ozone Dose which is the accumulated ozone uptake through stomata over the growing season, and above a threshold $\mathrm{Y}$ of uptake (PODY). By using a chemistry transport model, we found that European-averaged ground-level ozone concentrations $(-2 \%)$ and AOT40 metric $(-26.5 \%)$ significantly declined from 2000 to 2014, due to successful control strategies to reduce the emission of ozone precursors in Europe since the early 1990s. In contrast, the stomatal ozone uptake by forests increased from 17.5 to $26.6 \mathrm{mmol} \mathrm{O}_{3} \mathrm{~m}^{-2}$ despite the reduction in ozone concentrations, leading to an increase of
\end{abstract}

Project funding: This work was carried out with the contribution of the LIFE financial instrument of the European Union in the framework of the MOTTLES project "Monitoring ozone injury for setting new critical levels" (LIFE15 ENV/IT/000183).

The online version is available at https://www.springerlink.com

Corresponding editor: Yu Lei.

Alessandra De Marco

alessandro.anav@enea.it; alessandra.demarco@enea.it

1 Italian Institute for Environmental Protection and Research (ISPRA), via Brancati 48, 00144 Rome, Italy

2 ARGANS, 260 route du Pin Montard, 06410 Biot, France

3 Italian National Agency for New Technologies, Energy and the Environment, C.R. Casaccia, 00123 Rome, Italy

4 IRET-CNR, Via Madonna del Piano 10, Florence, 50019 Sesto Fiorentino, Italy potential ozone damage on plants in Europe. In a climate change context, a biologically-sound stomatal flux-based standard (PODY) as new European legislative standard is needed.

Keywords Tropospheric ozone - AOT40 • POD · Trendm $\cdot$ Mann-Kendall test

\section{Introduction}

Tropospheric ozone $\left(\mathrm{O}_{3}\right)$ is a secondary short-lived climate pollutant (Shindell et al. 2012), formed by the photochemical oxidation of $\mathrm{NO}_{\mathrm{x}}$ in the presence of carbon monoxide $(\mathrm{CO})$, methane $\left(\mathrm{CH}_{4}\right)$ and volatile organic compounds (VOCs) (Chameides et al. 1988). It is also the third most important greenhouse gas in terms of radiative forcing (Mickley et al. 2001). Despite the implementation of legislative standards to control the emission of $\mathrm{O}_{3}$ precursors worldwide (Cooper et al. 2014; Monks et al. 2015; Simon et al. 2015; Sicard et al. 2016a), $\mathrm{O}_{3}$ concentrations remain potentially harmful to vegetation over some regions around the world (Sicard et al. 2016a, 2017; Cailleret et al. 2018; Mills et al. 2018). In Europe, surface $\mathrm{O}_{3}$ pollution appears as a major air quality issue (Sicard et al. 2013, 2018, 2020a,b; EEA 2018), particularly in Southern Europe where road traffic and industrial emissions, combined with higher solar radiation, enhance $\mathrm{O}_{3}$ formation (Millán et al. 2000), and causes threat to vegetation (e.g. Sanz et al. 2000; Paoletti 2006; Wittig et al. 2009; Anav et al. 2011; Mills et al. 2011; Sicard et al. 2016b). Currently, the European standard used to protect vegetation against negative impacts of $\mathrm{O}_{3}$ is the Accumulated Ozone over a Threshold of $40 \mathrm{ppb}$ (AOT40), i.e. the cumulative exposure to hourly $\mathrm{O}_{3}$ concentrations above $40 \mathrm{ppb}$ over the daylight hours of the growing season (Directive 2008/50/EC). In Europe, a target value of 9,000 ppb h, 
averaged over 5 years, is recommended by the Directive 2008/50/CE for the vegetation protection whilst a critical level of 5,000 ppb h is recommended by UNECE (2017) for forest protection. Although AOT40 metric is widely used, the $\mathrm{O}_{3}$ uptake through stomata is a better metric to assess plant damage because it estimates the quantity of $\mathrm{O}_{3}$ entering in the leaf tissues (Musselman et al. 2006; De Marco et al. 2015; Sicard et al. 2016c). The Phytotoxic Ozone Dose above a threshold $\mathrm{Y}$ of uptake (PODY) is the accumulated stomatal $\mathrm{O}_{3}$ flux over the growing season and can be modelled using the Deposition of Ozone and Stomatal Exchange (DO3SE) model (UNECE 2017). The threshold $Y$ represents a detoxification threshold below which any $\mathrm{O}_{3}$ molecule absorbed by the plant is detoxified (CLRTAP 2017). High ambient $\mathrm{O}_{3}$ levels may not damage plants when stomata are closed (Ronan et al. 2020). Conversely, high PODY and resulting damages can occur at low $\mathrm{O}_{3}$ levels when stomata are open under favourable environmental conditions such as optimal air temperature and soil moisture (Ronan et al. 2020). For these reasons, the stomatal flux-based approach is recommended as more realistic compared to the exposure-based approach (Paoletti and Manning 2007; Sicard et al. 2016c; Agathokleous et al. 2018).

The evaluation of temporal trends in air pollutant levels in European Union (EU) countries is an essential tool to assess the improvement of air quality due to emissions control strategies (Guerreiro et al. 2014). To date, many studies have investigated $\mathrm{O}_{3}$ trends for a small number of monitoring stations, in particular at rural sites representative of background $\mathrm{O}_{3}$ conditions (De Leeuw 2000). In 2016, a report was published by the co-operative programme for monitoring and evaluation of the long-range transport of air pollutants in Europe (EMEP) focusing on background sites showing the evolution of ground-level $\mathrm{O}_{3}$ over the time period 1990-2012 (Colette et al. 2017). The report highlighted a relatively flat trend for annual $\mathrm{O}_{3}$ mean concentrations at EMEP background stations whilst a reduction of $37 \%$ for AOT40 was found between 2002 and 2012. Sicard et al. (2016a) found a decline $(-27 \%)$ for $\mathrm{O}_{3}$ vegetation impact metrics at 332 background stations in France between 1999 and 2012. Similarly, Araminiené et al. (2019) found a decreasing trend over the time period 2001-2014 for $\mathrm{O}_{3}$ annual mean $(-1.3 \%)$ and AOT40 $(-16 \%)$ in Lithuania whereas they found an increase for POD0 $(+2.9 \%)$. Anav et al. (2019) found a decreasing trend of AOT40 $(-22 \%)$ and $\mathrm{O}_{3}$ concentrations $(-1.6 \%)$ and a slight increase of POD0 $(+5.9 \%)$ in Europe over the time period 2000-2014. In this study, we performed a spatio-temporal analysis of short-term annual trends in $\mathrm{O}_{3}$ exposure-based and flux-based metrics for the protection of forests for all European countries over the time period 2000-2014.

\section{Materials and methods}

\section{Environmental data: the WRF-CHIMERE modelling system}

Hourly air temperature data and $\mathrm{O}_{3}$ concentrations were obtained, respectively, from the Weather Research and Forecasting (WRF), a mesoscale meteorological model (Skamarock and Klemp 2008) and CHIMERE, an Eulerian offline chemistry-transport model developed to analyse the gas-phase chemistry, aerosol formation, transport and deposition at regional scale. Data were provided at 1-h temporal resolution and $12 \mathrm{~km} \times 12 \mathrm{~km}$ of spatial resolution over the time period 2000-2014. The $\mathrm{O}_{3}$ concentrations at $20-25 \mathrm{~m}$ of height from the ground (top of the canopy) provided by the CHIMERE model were used to calculate AOT40 and PODY. Further information about the validation of data obtained by the WRF-CHIMERE modelling system can be found in Menut et al. (2013), Martin et al. (2014) and Anav et al. (2016).

\section{Calculation of $\mathrm{O}_{3}$ metrics}

\section{AOT40 calculation}

The $\mathrm{O}_{3}$ exposure index AOT40 (in ppb hours, abbreviated to $\mathrm{ppb} h$ ) was calculated as sum of the hourly exceedances above $40 \mathrm{ppb}$, for daylight hours ( $8 \mathrm{am}-8 \mathrm{pm}$ ) during the growing season, i.e. 1st April-30th September for the protection of forest trees (UNECE 2010), according to the methodology for $\mathrm{O}_{3}$ risk assessment in Europe.

$\mathrm{AOT} 40=\int_{i=1}^{n} \max (([O 3]-40), 0) . d t$

where $\left[\mathrm{O}_{3}\right]$ is hourly $\mathrm{O}_{3}$ concentration (ppb), n denotes the number of hours to be included in the calculation period and $d t$ is time step (1-h). The function "maximum" ensures that only values exceeding $40 \mathrm{ppb}$ are taken into account. In Europe, the critical values for the protection of forests is $5000 \mathrm{ppb} h$ as recommended by UNECE (2010).

However, Klingberg et al. (2014) showed that AOT40 does not consider the influence of climate change on the growing season duration. By consequence, we used in this study the AOT40 formula proposed by Anav et al. (2016) that is more plausible from a physiological point of view as the revised AOT40 was calculated from 1st January to 31 st December for hours with stomatal conductance $\left(g_{\text {sto }}\right)$ higher than 0 :

$$
\mathrm{AOT} 40=\int_{t=1 \text { Jan }}^{31 \text { Dec }} \max (([O 3]-40), 0) . d t ; \text { ssto }>0
$$


where $\left[\mathrm{O}_{3}\right]$ is the hourly $\mathrm{O}_{3}$ concentration (ppb), $d t$ is the time step (1-h) and $g_{\text {sto }}$ is the stomatal conductance computed according to Eq. (3). However, AOT40 does not provide any information on the $\mathrm{O}_{3}$ uptake by leaves (Anav et al. 2016).

\section{Phytotoxic ozone dose calculation}

The PODY was calculated using the $\mathrm{DO}_{3} \mathrm{SE}$ model, based on the multiplicative Jarvis' algorithm (Jarvis 1976) for estimation of $g_{\text {sto }}\left(\mathrm{mmol} \mathrm{O}_{3} \mathrm{~m}^{-2} \mathrm{~s}^{-1}\right)$. The $g_{\text {sto }}$ is calculated as a species-specific function where the maximum value of stomatal conductance $\left(g_{\max }\right)$ is reduced by limiting functions, scaled from 0 to 1 as described in Eq. 3 .

$g_{\text {sto }}=g_{\text {max }} \times f_{\text {phen }} \times f_{\text {light }} \times \max \left\{f_{\text {min }},\left(f_{\text {temp }} \times f_{V P D} \times f_{\text {SWC }}\right)\right\}$

where $g_{\max }$ is the maximum stomatal conductance of a plant species to $\mathrm{O}_{3}\left(\mathrm{mmol} \mathrm{O}_{3} \mathrm{~m}^{-2} \mathrm{~s}^{-1}\right.$ per leaf area). The functions $f_{\text {phen }}, f_{\text {light }}, f_{\text {temp }}, f_{V P D}$ and $f_{S W C}$ stand for the $\mathrm{g}_{\max }$ variation with leaf age, photosynthetically flux density at the leaf surface (PPFD, $\mu \mathrm{mol}$ photons $\mathrm{m}^{-2} \mathrm{~s}^{-1}$ ), surface air temperature, $\left(\mathrm{T},{ }^{\circ} \mathrm{C}\right)$, vapor pressure deficit (VPD, kPa) estimated through the surface air humidity, and volumetric soil water content $\left(\mathrm{SWC}, \mathrm{m}^{3} \mathrm{~m}^{-3}\right.$ ), respectively. The function $f_{\min }$ is the minimum $g_{\text {sto }}$ expressed as a fraction of $g_{\max }$. We assumed that $f_{\text {phen }}$ was 1 throughout the growing season. The following formulas were applied:

$f_{\text {light }}=1-\exp \left(-\right.$ light $_{a} *$ PPFD $)$

$f_{\text {temp }}=\left(\frac{\mathrm{T}-\mathrm{T}_{\min }}{\mathrm{T}_{\mathrm{opt}}-\mathrm{T}_{\min }}\right)\{\frac{\mathrm{T}_{\max }-\mathrm{T}}{\mathrm{T}_{\max }-\mathrm{T}_{\mathrm{opt}}} \underbrace{\left(\frac{\mathrm{T}_{\max }-\mathrm{T}_{\mathrm{opt}}}{\mathrm{T}_{\mathrm{opt}}-\mathrm{T}_{\min }}\right)}\}$

$f_{V P D}=\min \left[1, \max \left\{f_{\min },\left(\frac{\left(1-f_{\min }\right) *\left(V P D_{\min }-V P D\right)}{\left(V P D_{\min }-V P D_{\max }\right)}\right)+f_{\min }\right\}\right]$

$f_{\mathrm{SWC}}=\min \left[1,\left(f_{\min },\left(\left(1-f_{\min }\right) *\left(\frac{S W C-W P}{F C-W P}\right)+f_{\min }\right)\right)\right]$

where light $_{a}$ is an adimensional constant; PPFD is hourly photosynthetic photon flux density estimated through the solar radiation; $\mathrm{T}_{\mathrm{op}}, \mathrm{T}_{\min }$, and $\mathrm{T}_{\max }$, represent the optimum, minimum, and maximum temperature for stomatal conductance, respectively; $V P D_{\min }$ and $V P D_{\max }$ are minimum and maximum vapor pressure deficit for stomatal conductance, respectively; WP is SWC at wilting point and FC is SWC at field capacity. These two parameters are constant and depend on the soil type obtained from a module included into the WRF-CHIMERE model.
The dominant vegetation data, required to estimate $\mathrm{g}_{\text {sto }}$, were retrieved from the spatial tree distribution, based on the European Forest Institute database (Brus et al. 2011). Species-specific values of DO3SE parameters were derived from UNECE (2017) for each dominant plant species.

Once the stomatal conductance was computed, the stomatal $\mathrm{O}_{3}$ flux was calculated over the growing season and expressed as PODY (nmol O $\mathrm{m}^{-2} \mathrm{~s}^{-1}$ per leaf area). PODY $\left(\mathrm{mmol} \mathrm{m}{ }^{-2}\right)$ was calculated from hourly data as:

$P O D Y=\int_{i=1}^{n}\left[\left(g_{s t o} \times\left[O_{3}\right]-Y\right), 0\right] . d t$

where PODY is the accumulated stomatal $\mathrm{O}_{3}$ flux above a threshold Y over the growing, $g_{\text {sto }}$ represents the hourly stomatal conductance values, $\left[\mathrm{O}_{3}\right]$ is the hourly $\mathrm{O}_{3}$ concentrations (ppb) and $d t$ is the time step (1-h). PODY was calculated with $\mathrm{Y}=0 \mathrm{nmol} \mathrm{O}_{3} \mathrm{~m}^{-2} \mathrm{~s}^{-1}$ per leaf area, by considering that any $\mathrm{O}_{3}$ molecule is harmful for plants (Musselman et al. 2006), and $\mathrm{Y}=1 \mathrm{nmol} \mathrm{O} \mathrm{m}^{-2} \mathrm{~s}^{-1}$ per leaf area, as recommended by CLRTAP (2017).

\section{Estimation of annual trends}

A 10-year time-series of $\mathrm{O}_{3}$ data is considered long enough to assess short-term changes as reported in Sicard et al. (2016a). The non-parametric tests are robust and suitable for non-normally distributed data with missing and extreme values (Sicard et al. 2009). The non-parametric Mann-Kendall test was used to assess whether there is a monotonic upward or downward trend of $\mathrm{O}_{3}$ over time (Sicard et al. 2013; Guerreiro et al. 2014). To quantify linear trends, the non-parametric Sen's slope estimator was used (Sicard et al. 2013, 2016a; Araminienè et al. 2019). Annual trends were calculated for $\mathrm{O}_{3}$ metrics over the time period 2000-2014 for each European country as well as for four European regions as classified in UNECE (2010). Table 1 shows the regional classification of countries. The results are considered statistically significant at $p<0.05$.

\section{Results}

\section{European distribution of air temperature and ozone metrics}

Over the time period 2000-2014, the minimum annual air temperatures $\left(7.0 \pm 0.3{ }^{\circ} \mathrm{C}\right)$ occurred in Northern Europe while the maximum values $\left(12.7 \pm 0.5^{\circ} \mathrm{C}\right)$ were found in Mediterranean Europe (Fig. 1). Atlantic and Continental central Europe showed mean annual temperature ranging from 8.2 to $10.2{ }^{\circ} \mathrm{C}$ (Fig. 1). Taking into account mean $\mathrm{O}_{3}$ concentrations, Mediterranean Europe showed values 
Table 1 Regional classification of countries adopted in this study based on Manual on methodologies and criteria for modelling and mapping critical loads and levels of air pollution effects, risks and trends (UNECE 2017)

\begin{tabular}{ll}
\hline Region & Countries \\
\hline Atlantic central Europe & Belgium, Ireland, Luxembourg, Netherlands, Unite Kingdom \\
Continental central Europe & Austria, Belarus, Czech Republic, Finland, Faroe Is., France, Germany, \\
& Hungary, Slovakia, Liechtenstein, Moldova, Poland, Romania, Russia, \\
& Switzerland, Ukraine \\
Mediterranean Europe & Albania, Bosnia \& Herzegovina, Bulgaria, Greece, Croatia, Italy, Mac- \\
Northern Europe & edonia, Malta, Montenegro, Portugal, Slovenia, Spain, Serbia
\end{tabular}

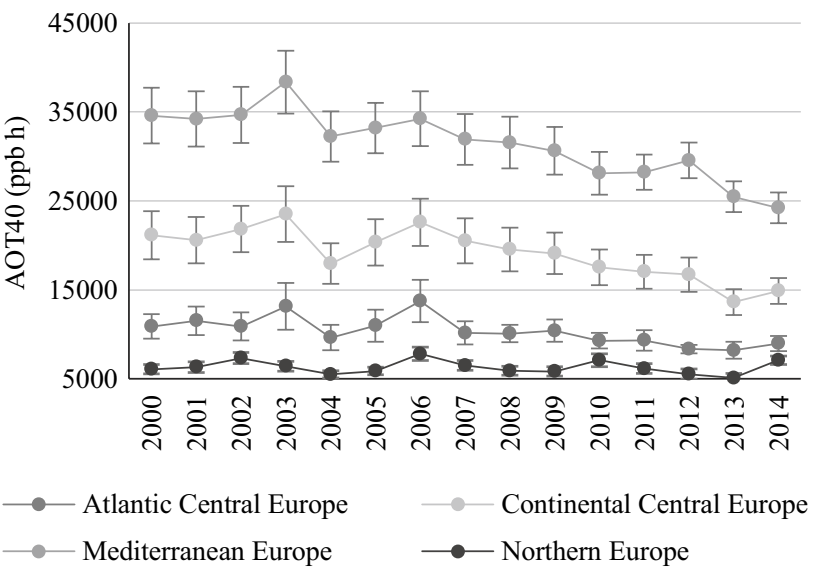

Fig. 3 Mean AOT40, i.e. accumulated exposure over a threshold of $40 \mathrm{ppb}$ (in ppb $\mathrm{h} \pm$ Standard Error) in Europe over the time period 2000-2014

23,515 ppb h while in Atlantic central Europe AOT40 varied from 8207 to $13,751 \mathrm{ppb}$ h (Fig. 3). Taking into account POD0 values, the minimum value $\left(14.0 \mathrm{mmol} \mathrm{O}_{3} \mathrm{~m}^{-2}\right)$ was found in 2006 in Northern Europe while the maximum values, 29.7 and $32.1 \mathrm{mmol} \mathrm{O}_{3} \mathrm{~m}^{-2}$ were observed in Atlantic and Mediterranean Europe, respectively (Fig. 4). Similar results were found for POD1 (Fig. 5).

\section{Trends in ground-level ozone metrics at European level}

The annual trend magnitudes for $\mathrm{O}_{3}$ concentrations, AOT40, POD0 and POD1 over the time period 2000-2014 are shown in Tables 2, 3, 4 and 5. The $\mathrm{O}_{3}$ mean concentrations decreased significantly $(p<0.05)$ by $0.4 \mathrm{ppb}$ per decade in Continental Central Europe and by $1.1 \mathrm{ppb}$ per decade in Mediterranean Europe (Table 2). In Atlantic Central Europe and Northern Europe, the trends for $\mathrm{O}_{3}$ mean concentration were not statistically significant (Table 2). The exposure index AOT40 significantly declined in Atlantic, Continental and Mediterranean Europe with a magnitude of 2124, 5532 and $7161 \mathrm{ppb}$ h per decade, respectively (Table 3). POD0 and POD1 increased significantly over the time period 2000-2014 all over Europe, except in Northern Europe showing a positive but not significant $(p>0.5)$ 


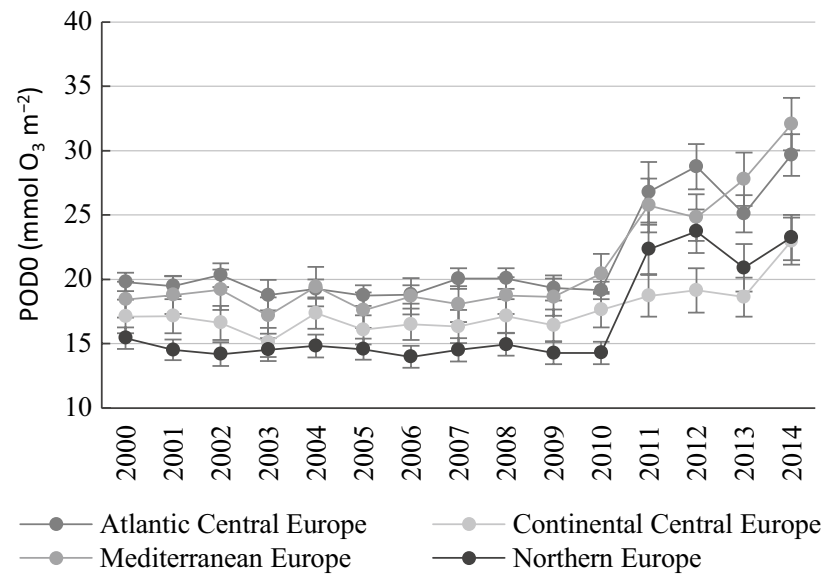

Fig. 4 Mean Phytotoxic Ozone Dose above a threshold $\mathrm{Y}$ of $0 \mathrm{nmol} \mathrm{m} \mathrm{s}^{-1}$ (POD0 in $\mathrm{mmol} \mathrm{O}_{3} \mathrm{~m}^{-2} \pm$ Standard Error) in Europe over the time period 2000-2014

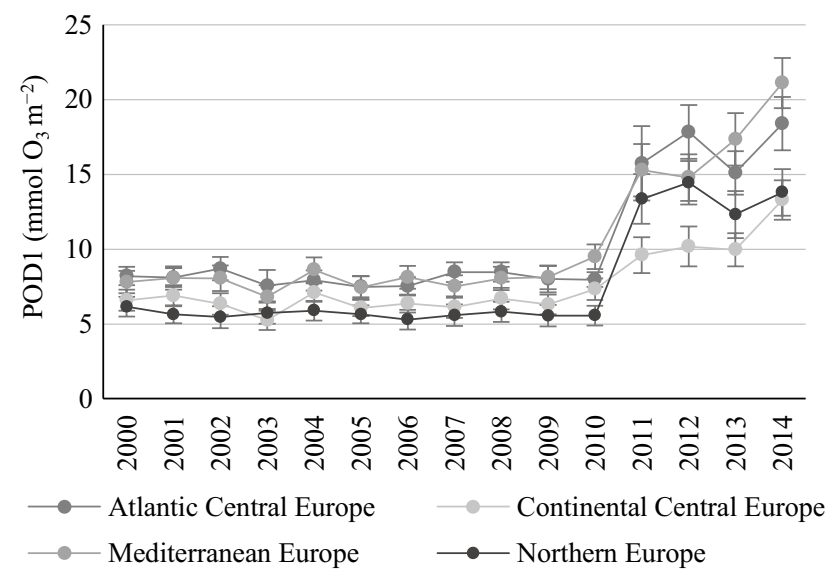

Fig. 5 Mean Phytotoxic Ozone Dose above a threshold $\mathrm{Y}$ of $1 \mathrm{nmol} \mathrm{m} \mathrm{m}^{-2} \mathrm{~s}^{-1}$ (POD1 in mmol. $\mathrm{O}_{3} \mathrm{~m}^{-2} \pm$ Standard Error) in Europe over the time period 2000-2014

Table 2 Regional average \pm standard deviation (SD) and annual trend, obtained by the Mann Kendall test for ozone concentrations over the time period 2000-2014 (not significant, ns)

\begin{tabular}{lllll}
\hline Region & \multicolumn{5}{c}{ Ozone concentrations (2000-2014) } \\
\cline { 2 - 5 } & Mean & SD & Trend (ppb/year) & $p$ value \\
\hline Atlantic central Europe & 32.53 & 0.35 & 0.00 & $\mathrm{~ns}$ \\
Continental central Europe & 37.21 & 0.30 & -0.04 & $<0.05$ \\
Mediterranean Europe & 43.90 & 0.61 & -0.11 & $<0.05$ \\
Northern Europe & 34.58 & 0.21 & 0.01 & $\mathrm{Ns}$ \\
\hline
\end{tabular}

trend (Tables 4, 5). POD0 and POD1 increased by 4.3 and $3.3 \mathrm{mmol} \mathrm{O}_{3} \mathrm{~m}^{-2}$ per decade in Atlantic Central Europe respectively, and by 2.4 and $3.0 \mathrm{mmol} \mathrm{O}_{3} \mathrm{~m}^{-2}$ per decade in
Table 3 Regional average \pm standard deviation (SD) and annual trend, obtained by the Mann Kendall test for AOT40 over the time period 2000-2014 (not significant, ns)

\begin{tabular}{lllll}
\hline Region & \multicolumn{4}{l}{ AOT40 $(2000-2014)$} \\
\cline { 2 - 5 } & Mean & SD & Trend (ppb h/year) & $p$ value \\
\hline $\begin{array}{l}\text { Atlantic central } \\
\text { Europe }\end{array}$ & $10,371.4$ & 1581.5 & -212.5 & $<0.05$ \\
$\begin{array}{l}\text { Continental central } \\
\text { Europe }\end{array}$ & $19,134.3$ & 2812.6 & -553.2 & $<0.05$ \\
$\begin{array}{l}\text { Mediterranean } \\
\text { Europe }\end{array}$ & $31,415.7$ & 3790.2 & -716.2 & $<0.05$ \\
Northern Europe & 6302.3 & 755.2 & -34.7 & Ns \\
\hline
\end{tabular}

Table 4 Regional average \pm standard deviation (SD) and annual trend, obtained by the Mann Kendall test for POD0 over the time period 2000-2014 (not significant, ns)

\begin{tabular}{lllll}
\hline Region & \multicolumn{4}{l}{ POD0 (2000-2014) } \\
\cline { 2 - 5 } & Mean & SD & $\begin{array}{l}\text { Trend }(\mathrm{mmol} \\
\left.\mathrm{m}^{-2} / \text { year }\right)\end{array}$ & $p$ value \\
\hline Atlantic central Europe & 21.6 & 3.9 & 0.43 & $<0.05$ \\
Continental central Europe & 17.5 & 1.8 & 0.24 & $<0.05$ \\
Mediterranean Europe & 21.0 & 4.4 & 0.57 & $<0.05$ \\
Northern Europe & 16.7 & 3.7 & 0.29 & $\mathrm{Ns}$ \\
\hline
\end{tabular}

Table 5 Regional average \pm standard deviation (SD) and annual trend, obtained by the Mann Kendall test for POD1 over the time period 2000-2014 (not significant, ns)

\begin{tabular}{lrrll}
\hline Region & \multicolumn{3}{l}{ POD1 (2000-2014) } & \\
\cline { 2 - 5 } & Mean & SD & $\begin{array}{l}\text { Trend (mmol } \\
\left.\mathrm{m}^{-2} / \text { year }\right)\end{array}$ & $p$ value \\
\hline Atlantic central Europe & 10.4 & 4.1 & 0.33 & $<0.05$ \\
Continental central Europe & 7.6 & 2.2 & 0.30 & $<0.05$ \\
Mediterranean Europe & 10.4 & 4.4 & 0.61 & $<0.05$ \\
Northern Europe & 7.7 & 3.6 & 0.15 & $\mathrm{Ns}$ \\
\hline
\end{tabular}

Continental Central Europe while higher trend magnitudes were found in Mediterranean Europe: POD0 and POD1 significantly increased by 5.7 and $6.1 \mathrm{mmol} \mathrm{O}_{3} \mathrm{~m}^{-2}$ per decade, respectively. It is important to underline that POD0 and POD1 values are increasing since 2010.

\section{Trends in ground-level ozone metrics at country-level}

Over the time period 2000-2014, the exposure AOT40 index significantly declined in most of European countries (Fig. 6a). The lowest value was found in Switzerland $\left(-1376 \mathrm{ppb} \mathrm{h} \mathrm{year}^{-1}\right)$ and the highest values were observed in the Isle of Man (self-governing British Island) and Malta 


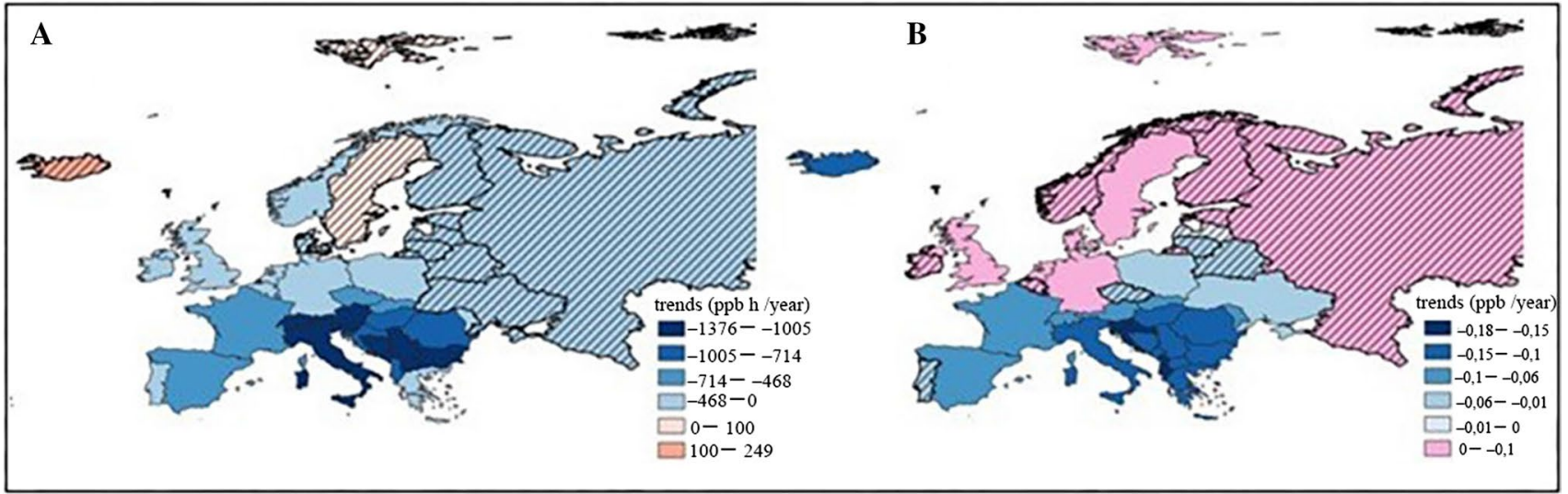

Fig. 6 Annual trends for AOT40 (in ppb h per year) a and ozone concentrations (in ppb) b in European countries. Blue color is for negative trends, pink for positive ones. Countries with not significant trends $(p>0.05)$ are striped

(+200 ppb h year ${ }^{-1}$ and $+249 \mathrm{ppb}$ h year $^{-1}$ respectively). Similar results were found for trends in $\mathrm{O}_{3}$ concentrations (Fig. 6b). In particular, only six countries showed positive trends (Denmark, United Kingdom, the Netherlands, Germany, Sweden and Svalbard). On the contrary, trends of POD0 and POD1 were positive in all countries (Fig. 7a and b) with minimum values of +0.03 and $+0.04 \mathrm{mmol} \mathrm{m}^{-2}$ per year and maximum values of +1.06 and $+0.93 \mathrm{mmol} \mathrm{m}^{-2}$ per year for POD0 and POD1, respectively.

\section{Discussion and conclusions}

Our results showed a general decrease of $\mathrm{O}_{3}$ concentrations and exposure-based index, namely AOT40, all over Europe and a general increase of flux-based metrics (POD0 and POD1) over the time-period 2000-2014. These results are in line with other studies conducted in different European countries. Anav et al. (2019) found that $\mathrm{O}_{3}$ concentrations and AOT40 declined all over Europe from 2000 to 2014, while PODY did not. Karlsson et al. (2017) found a significantly decreasing trends of AOT40 in Fennoscandia and United Kingdom over the time period 1990-2015 highlighting that AOT40 is projected to no longer exceed the critical level established for forest protection for most of Northern Europe by 2050, while POD1 does not fall below its critical level. Similarly, the analysis conducted by Mills et al. (2018) at global level by using the international Tropospheric Ozone Assessment Report (TOAR) database showed a statistically significant decreasing trends of $45 \%$ of AOT 40 (for perennial vegetation) and highlighted the reduction of AOT40 at many European sites. At country level, Araminienè et al. (2019) found negative trends of $\mathrm{O}_{3}$ concentrations $\left(-0.28 \mathrm{ppb}\right.$ decade $\left.^{-1}\right)$ and AOT40 $\left(-2,540 \mathrm{ppb} \mathrm{h}\right.$ decade $\left.^{-1}\right)$ but a positive trend for POD0 $\left(+0.39 \mathrm{mmol} \mathrm{O}_{3} \mathrm{~m}^{-2}\right.$ decade $\left.^{-1}\right)$ in Lithuania. Our results demonstrate the large-scale success of European control strategies, such as the Air Quality Framework

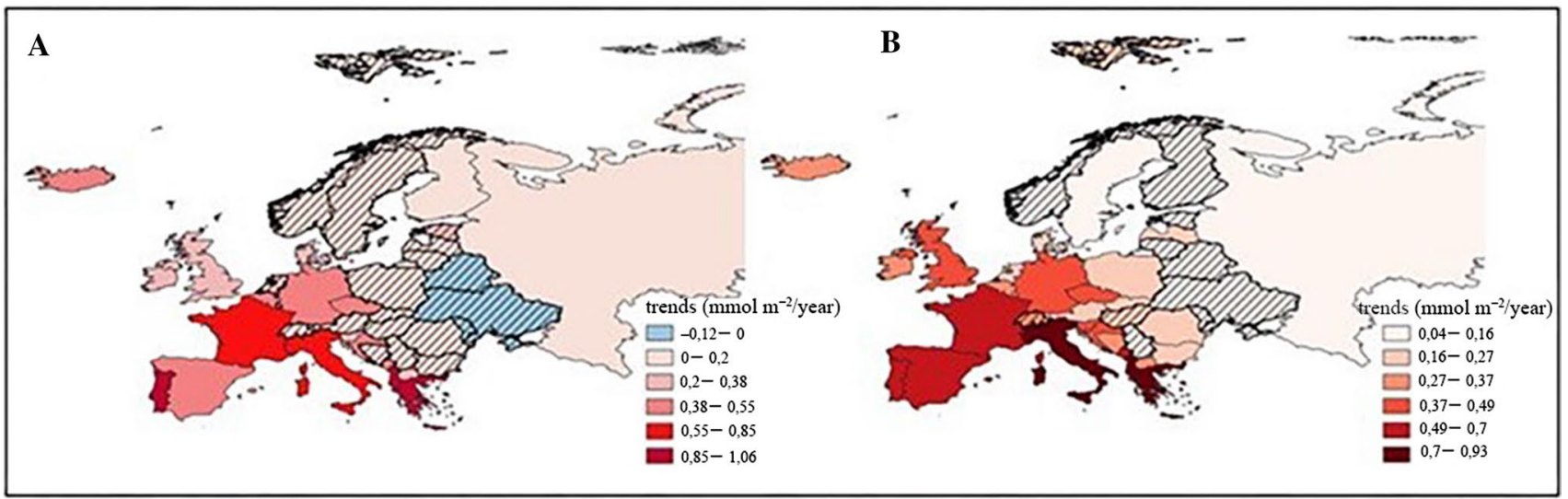

Fig. 7 Annual trends for POD0 a and POD1 $\mathbf{b}$ (in mmol $\mathrm{O}_{3} \mathrm{~m}^{-2}$ per year) in European countries. Blue color is for negative trends, red for positive ones. Countries with not significant trends $(p>0.05)$ are striped 
Directive (96/62/EC), Large Combustion Plant Directive (2001/80/EC), National Emission Ceilings Directives (2001/81/EC) and the Gothenburg Protocol (1999) under the United Nations Convention on Long-Range Transboundary Air Pollution (LRTAP), targeted at decreasing peak $\mathrm{O}_{3}$ levels and reducing the risk of $\mathrm{O}_{3}$ impacts on vegetation and human health. The emission reductions have primarily been achieved as a result of the progress in vehicle technologies, the stringent inspection systems legislation related to the "Euro" standards, the use of flue gas abatement techniques, the progress in the storage and distribution of solvents (Vestreng et al. 2008; EEA 2018; Sicard et al. 2020b). However, our results showed a general increase of PODY all over Europe between 2000 and 2014 highlighting the relative insensitivity of PODY to $\mathrm{O}_{3}$ precursors control strategies. Climate change is identified as the responsible of this insensitivity as postulated in previous studies (Liu et al. 2016a, b; Fu et al. 2017; Anav et al. 2019). They reported earlier green-up dates and delayed dormancy dates then a longer growing season due to changing climate. Moreover, climate change increases the stomatal conductance thanks to the positive effects of higher air temperature and solar radiation on stomata opening (Hoshika et al. 2015). Even if the $\mathrm{O}_{3}$ mean concentrations decreased, higher PODY levels were observed over time leading to higher $\mathrm{O}_{3}$ risk to European forests (Proietti et al. 2016; Anav et al. 2019). Anav et al. (2019) hypothesized that the positive feedback between climate change and PODY will increase in the near future and the efforts in controlling emissions of $\mathrm{O}_{3}$ precursors could be significantly offset by climate change, thus increasing the $\mathrm{O}_{3}$ risk for forests. A primary goal is to define a metric for $\mathrm{O}_{3}$-risk assessment, which can identify ecosystems at $\mathrm{O}_{3}$ risk to protect them using standards and policies. In Europe, AOT40 has been widely used, under the assumption that plant injury and exposure to $\mathrm{O}_{3}$ concentrations are correlated (EPA 2007; UNECE 2011; Fares et al. 2013). To date, several studies report a general growing consensus for moving toward a biologically-sound stomatal flux-based standard (PODY) as new European legislative standard (Mills et al. 2011; Fares et al. 2013; Sicard et al. 2016b,c; Anav et al. 2016, 2019) although critical levels for vegetation protection still need to be validated (Sicard et al. 2016c). Epidemiological observation of $\mathrm{O}_{3}$-induced injury and environmental variables including $\mathrm{O}_{3}$ can be used to derive consistent stomatal flux-based critical levels for different type of vegetation under natural field conditions (De Marco and Sicard 2019; Paoletti et al. 2019). The question about deriving new critical levels is still a challenge for the scientific community (De Marco and Sicard 2019), even because some advantage of AOT40 are still present. Indeed the simplicity and fast applicability of AOT40 could be an advantage for the use of the concentration-based metric (Anav et al. 2016). But on the other side AOT40 is not taking into consideration more biological processes linked to the stomatal aperture and can have spatially and temporally different patterns (De Marco et al. 2015). These consideration highlights the role of climate into determination of the impacts of ozone on forests. Consequently, strategies integrating both climate and air quality policies are urgently needed for forest protection against the negative impacts of $\mathrm{O}_{3}$ (Ainsworth et al. 2012).

Funding Open access funding provided by Ente per le Nuove Tecnologie, l'Energia e l'Ambiente within the CRUI-CARE Agreement.

Open Access This article is licensed under a Creative Commons Attribution 4.0 International License, which permits use, sharing, adaptation, distribution and reproduction in any medium or format, as long as you give appropriate credit to the original author(s) and the source, provide a link to the Creative Commons licence, and indicate if changes were made. The images or other third party material in this article are included in the article's Creative Commons licence, unless indicated otherwise in a credit line to the material. If material is not included in the article's Creative Commons licence and your intended use is not permitted by statutory regulation or exceeds the permitted use, you will need to obtain permission directly from the copyright holder. To view a copy of this licence, visit http://creativecommons.org/licenses/by/4.0/.

\section{References}

Agathokleous E, Kitao M, Kinose Y (2018) A review study on ozone phytotoxicity metrics for setting critical levels in Asia. Asian J Atmos Environ 12:1-16

Ainsworth EA, Yendrek CR, Sitch S, Collins WJ, Emberson LD (2012) The effects of tropospheric ozone on net primary productivity and implications for climate change. Annu Rev Plant Biol 63:637-661

Anav A, Menut L, Khvorostyanov D, Viovy N (2011) Impact of tropospheric ozone on the Euro-Mediterranean vegetation. Glob Change Biol 17:2342-2359

Anav A, De Marco A, Proietti C, Alessandri A, Dell'Aquila A, Cionni I, Friedlingstein P, Khvorostyanov D, Menut L, Paoletti E, Sicard P, Sitch S, Vitale M (2016) Comparing concentration-based (AOT40) and stomatal uptake (PODY) metrics for ozone risk assessment to European forests. Glob Change Biol 22:1608-1627

Anav A, De Marco A, Friedlingstein P, Savi F, Sicard P, Sitch S, Vitale M, Paoletti E (2019) Growing season extension affects ozone uptake by European forests. Sci Total Environ 669:1043-1052

Araminienė V, Sicard P, Anav A, Agathokleous E, Stakėnas V, De Marco A, Varnagirytė-Kabašinskienė I, Paoletti E, Girgždienè R (2019) Trends and inter-relationships of ground-level ozone metrics and forest health in Lithuania. Sci Total Environ 658:1265-1277

Brus DJ, Hengeveld GM, Walvoort DJJ, Goedhart PW, Heidema AH, Nabuurs GJ, Gunia K (2011) Statistical mapping of tree species over Europe. Eur J For Res 131:145-157

Cailleret M, Ferretti M, Gessler A, Rigling A, Schaub M (2018) Ozone effects on European forest growth-towards an integrative approach. J Ecol 106:1377-1389 
CLRTAP (2017) Mapping critical loads for ecosystems, Chapter V of Manual on methodologies and criteria for modelling and mapping critical loads and levels and air pollution effects, risks and trends

Chameides WL, Lindsay RW, Richardson J, Kiang CS (1988) The role of biogenic hydrocarbons in urban photochemical smog: Atlanta as a case study. Science 241:1473-1475

Colette A, Solberg S, Beauchamp M, Bessagnet B, Mal-herbe L, Guerreiro C (2017) Long term air quality trendsin Europe: contribution of meteorological variability, natu-ral factors and emissions. ETC/ ACM, Bilthoven

Cooper OR, Parrish DD, Ziemke J, Balashov NV, Cupeiro M, Galbally IE, Gilge S, Horowitz L, Jensen NR, Lamarque JF, Naik V, Oltmans SJ, Schwab J, Shindell DT, Thompson AM, Thouret V, Wang Y, Zbinden RM (2014) Global distribution and trends of tropospheric ozone: an observation-based review. Elementa 2:29

De Leeuw F (2000) Trends in ground level ozone concentrations in the European Union. Environ Sci Policy 3:189-199

De Marco A, Sicard P (2019) Why do we still need to derive ozone critical levels for vegetation protection. Int J Environ Sci Nat Resour 21:164-166

De Marco A, Sicard P, Vitale M, Carriero G, Renou C, Paoletti E (2015) Metrics of ozone risk assessment for Southern European forests: testing the potential of canopy moisture content as plant response indicator. Atmos Environ 120:182-190

EPA (2007) Review of the National Ambient Air Quality Standards for Ozone: Policy Assessment of Scientific and Technical Information. OAQPS Staff Paper. U.S. Environmental Protection Agency, Office of Air Quality Planning and Standards, Research Triangle Park, Durham NC. Publication No. EPA-452/R-07-003

EEA (2018) European Environment Agency: Air quality in Europe. 2018 report. ISBN 978-92-9213-989-6. https://doi. org/10.2800/777411.

Fares S, Vargas R, Detto M, Goldstein AH, Karlik J, Paoletti E, Vitale M (2013) Tropospheric ozone reduces carbon assimilation in trees: estimates from analysis of continuous flux measurements. Glob Change Biol 19:2427-2443

Fu YSH, Piao SL, Delpierre N, Hao FH, Hänninen H, Liu YJ, Sun WC, Janssens IA, Campioli M (2017) Larger temperature response of autumn leaf senescence than spring leaf-out phenology. Glob Change Biol 24:2159-2168

Guerreiro CBB, Foltescu V, de Leeuw F (2014) Air quality status and trends in Europe. Atmos Environ 98:376-384

Hoshika Y, Katata G, Deushi M, Watanabe M, Koike T, Paoletti E (2015) Ozone-induced stomatal sluggishness changes carbon and water balance of temperate deciduous forests. Sci Rep 5:9871

Jarvis PG (1976) The interpretation of the variations in leaf water potential and stomatal conductance found in canopies in the field. Philos Trans R Soc Lond B 273:593-610

Karlsson PE, Klingberg J, Engardt M, Andersson C, Langner J, Karlsson GP, Pleijel H (2017) Past, present and future concentrations of ground-level ozone and potential impacts on ecosystems and human health in northern Europe. Sci Total Environ 576:22-35

Klingberg J, Engardt M, Karlsson PE, Langner J, Pleijel H (2014) Declining ozone exposure of European vegetation under climate change and reduced precursor emissions. Biogeosciences 11:5269-5283

Liu Q, Fu YSH, Zeng ZZ, Huang MT, Li XR, Piao SL (2016a) Temperature, precipitation, and insolation effects on autumn vegetation phenology in temperate China. Glob Change Biol 22:644-655

Liu Q, Fu YSH, Zhu ZC, Liu YW, Liu Z, Huang MT, Janssens IA, Piao SL (2016b) Delayed autumn phenology in the Northern Hemisphere is related to change in both climate and spring phenology. Glob Change Biol 22:3702-3711

Martin F, Fileni L, Palomino I, Vivanco MG, Garrido JL (2014) Analysis of the spatial representativeness of rural background monitoring stations in Spain. Atmos Pollut Res 5:779-788
Menut L, Bessagnet B, Khvorostiyanov D, Beekmann M, Blond N, Colette A, Coll I, Curci G, Foret G, Hodzic A, Mailler S, Meleux F, Monge JL, Pison I, Siour G, Turquety S, Valari M, Vautard R, Vivanco MG (2013) CHIMERE 2013: a model for regional atmospheric composition modelling. Geosci Model Dev 6:981-1028

Mickley LJ, Jacob DL, Rind D (2001) Uncertainty in preindustrial abundance of tropospheric ozone: implications for radiative forcing calculations. J Geophys Res 106:3389-3399

Millán MM, Mantilla E, Salvador R, Carratalá A, Sanz MJ, Alonso L, Gangoiti G, Navazo M (2000) Ozone cycles in the Western Mediterranean basin: interpretation of monitoring data in complex coastal terrain. J Appl Meteorol 39:487-508

Mills G, Pleijel H, Braun S, Buker P, Bermejo V, Calvo E, Danielsson H, Emberson L, Fernandez IG, Grunhage L, Harmens H, Hayes F, Karlsson PE, Simpson D (2011) New stomatal flux-based critical levels for ozone effects on vegetation. Atmos Environ 45:5064-5068

Mills G, Sharps K, Simpson D, Pleijel H, Broberg M, Uddling J, Jaramillo F, Davies WJ, Dentener F, Van den Berg M, Agrawal M, Agrawal SB, Ainsworth EA, Buker P, Emberson L, Feng ZZ, Harmens H, Hayes F, Kobayashi K, Paoletti E, Van Dingenen R (2018) Ozone pollution will compromise efforts to increase global wheat production. Glob Change Biol 24(8):3560-3574. https:// doi.org/10.1111/gcb.14157

Monks PS, Archibald AT, Colette A, Cooper O, Coyle M, Derwent R, Fowler D, Granier C, Law KS, Mills GE, Stevenson DS, Tarasova O, Thouret V, von Schneidemesser E, Sommariva R, Wild O, Williams M (2015) Tropospheric ozone and its precursors from the urban to the global scale from air quality to shortlived climate forcer. Atmos Chem Phys 15:8889-8973

Musselman RC, Lefohn AS, Massman WJ, Heath RL (2006) A critical review and analysis of the use of exposure- and flux-based ozone indices for predicting vegetation effects. Atmos Environ 40:1869-1888

Paoletti E, Alivernini A, Anav A, Badea O, Carrari E, Chivulescu S, Conte A, Ciriani ML, Dalstein-Richier L, De Marco A, Fares S, Fasano G, Giovannelli A, Lazzara M, Leca S, Materassi S, Moretti V, Pitar D, Popa I, Sabatini F, Salvati L, Sicard P, Sorgi T, Hoshika Y (2019) Toward stomatal-flux based forest protection against ozone: the MOTTLES approach. Sci Total Environ 691:516-527

Paoletti E (2006) Impact of ozone on Mediterranean forests: a review. Environ Pollut 144:463-474

Paoletti E, Manning WJ (2007) Toward a biologically significant and usable standard for ozone that will also protect plants. Environ Pollut 150:85-95

Proietti C, Anav A, DeMarco A, Sicard P, Vitale M (2016) A multisites analysis on the ozone effects on gross primary production of European forests. Sci Total Environ 556:1-11

Ronan AC, Ducker JA, Schnell JL, Holmes CD (2020) Have improvements in ozone air quality reduced ozone uptake into plants? Elem Sci Anth 8:2

Sanz MJ, Calatayud V, Calvo E (2000) Spatial pattern of ozone injury in Aleppo pine related to air pollution dynamics in a coastalmountain region of eastern Spain. Environ Pollut 108:239-247

Shindell D, Kuylenstierna JCI, Vignati E, van Dingenen R, Amann M, Klimont Z, Anenberg SC, Muller N, Janssens-Maenhout G, Raes F, Schwartz J, Faluvegi G, Pozzoli L, Kupiainen K, Höglund-Isaksson L, Emberson L, Streets D, Ramanathan V, Hicks K, Oanh NTK, Milly G, Williams M, Demkine V, Fowler D (2012) Simultaneously mitigating near-term climate change and improving human health and food security. Science 335:183-189

Sicard P, Coddeville P, Galloo JC (2009) Near-surface ozone levels and trends at rural stations in France over the 1995-2003 period. Environ Monit Assess 156:141-157 
Sicard P, Thibaudon M, Besancenot JP, Mangin A (2013) Forecast models and trends for the main characteristics of the Olea pollen season in Nice (south-eastern France) over the 1990-2009 period. Grana 51:52-62

Sicard P, Serra R, Rossello P (2016a) Spatio-temporal trends of surface ozone concentrations and metrics in France. Environ Res 149:122-144

Sicard P, Augustaitis A, Belyazid S, Calfapietra C, De Marco A, Fenn M, Grulke N, He S, Matyssek R, Serengil Y, Wieser G, Paoletti E (2016b) Global topics and novel approaches in the study of air pollution, climate change and forest ecosystems. Environ Pollut 213:977-987

Sicard P, De Marco A, Dalstein-Richier L, Tagliaferro F, Paoletti E (2016c) An epidemiological assessment of stomatal ozone fluxbased critical levels for visible ozone injury in Southern European forests. Sci Total Environ 541:729-741

Sicard P, Anav A, De Marco A, Paoletti E (2017) Projected global tropospheric ozone impacts on vegetation under different emission and climate scenarios. Atmos Chem Phys 17:12177-12196

Sicard P, Agathokleous E, Araminiene V, Carrari E, Hoshika Y, De Marco A, Paoletti E (2018) Should we see urban trees as effective solutions to reduce increasing ozone levels in cities? Environ Pollut 243:163-176

Sicard P, Khaniabadi YO, Perez S, Gualtieri M, De Marco A (2019) Effect of $\mathrm{O}_{3}, \mathrm{PM} 10$ and PM2.5 on cardiovascular and respiratory diseases in cities of France, Iran and Italy. Environ Sci Pollut Res 26:32645-32665

Sicard P, De Marco A, Agathokleous E, Feng ZZ, Xu XB, Paoletti E, Diéguez Rodriguez JJ, Calatayud V (2020a) Amplified ozone pollution in cities during the COVID-19 lockdown. Sci Total Environ 735:139542

Sicard P, Paoletti E, Agathokleous E, Araminienė V, Proietti C, Coulibaly F, De Marco A (2020b) Ozone weekend effect in cities: Deep insights for urban air pollution control. Environ Res 191:110193
Simon H, Reff A, Wells B, Xing J, Frank N (2015) Ozone trends across the United States over a period of decreasing NOx and VOC emissions. Environ Sci Tech 49:186-195

Skamarock W, Klemp JB (2008) A time-split non-hydrostatic atmospheric model for weather research and forecasting applications. J Comput Phys 227:3465-3485

UNECE (2010) Mapping critical levels for vegetation. Manual on methodologies and criteria for modelling and mapping critical loads and levels and air pollution effects, risks and trends, United Nations Economic Commission for Europe (UNECE) convention on long range transboundary air pollution, Geneva p 254. https:// www.icpmapping.org

UNECE (2011) Manual on methodologies and criteria for modelling and mapping critical loads and levels and air pollution effects, risks and trends. Convention on long-range transboundary air pollution. https://www.icpmapping.org. Accessed November 2012

UNECE (2017) Mapping critical levels for vegetation. International cooperative programme on effects of air pollution on natural vegetation and crops, Bangor, UK

Vestreng V, Ntziachristos L, Semb A, Reis S, Isaksen ISA, Tarrasón L (2008) Evolution of NOx emissions in Europe with focus on road transport control measures. Atmos Chem Phys Discuss 8:10697-10747

Wittig VE, Ainsworth EA, Naidu SL, Karnosky DF, Long SP (2009) Quantifying the impact of current and future tropospheric ozone on tree biomass, growth, physiology and biochemistry: a quantitative meta-analysis. Glob Change Biol 15:396-424

Publisher's Note Springer Nature remains neutral with regard to jurisdictional claims in published maps and institutional affiliations. 